\begin{tabular}{|l|l|l|}
\hline \multicolumn{2}{|c|}{ PublisherInfo } \\
\hline \hline PublisherName & $:$ & BioMed Central \\
\hline \hline PublisherLocation & $:$ & London \\
\hline \hline PublisherImprintName & $:$ & BioMed Central \\
\hline \hline
\end{tabular}

\title{
Where to look for steroid receptor information
}

\begin{tabular}{|l|l|l||}
\hline \multicolumn{2}{|c||}{ ArticleInfo } \\
\hline \hline ArticleID & $:$ & 4296 \\
\hline \hline ArticleDOI & $:$ & $10.1186 /$ gb-2001-3-1-reports2003 \\
\hline \hline ArticleCitationID & $:$ & reports2003 \\
\hline \hline ArticleSequenceNumber & $:$ & 28 \\
\hline \hline ArticleCategory & $:$ & Web report \\
\hline \hline ArticleFirstPage & $:$ & 1 \\
\hline \hline ArticleLastPage & $:$ & 3 \\
\hline \hline & & RegistrationDate : 2001-11-19 \\
ArticleHistory & $:$ & Received \\
\hline ArticleCopyright & $:$ & BioMed Central Ltd2001-11-19 \\
\hline \hline ArticleGrants & $:$ & \\
\hline \hline ArticleContext & $:$ & 130593311 \\
\hline \hline
\end{tabular}




\section{Eliezer Kopf}

\section{Abstract}

The Nuclear Receptor Resource (NRR) provides an intergrated collection of databases on members of the steroid and thyroid hormone receptor superfamily

\section{Content}

The Nuclear Receptor Resource (NRR) provides an intergrated collection of databases on members of the steroid and thyroid hormone receptor superfamily. Some of the databases deal with individual receptors and provide large amounts of information on receptor genes and proteins, such as: graphical demonstrations of the receptors, structural design of the hormones and a list of mutations in the receptors. The site also includes general links to useful information on researchers in the field, lists of jobs, and meetings. Researchers are invited to provide information or to maintain a web page on an individual receptor.

\section{Navigation}

The navigation between links is quick, and some information, such as figures, can be easily downloaded to other programs.

\section{Reporter's comments}

\section{Timeliness}

Update times are not given, but the most recent 'Positions Available' and meetings postings are from August 2001. 


\section{Best feature}

The bringing together of many different sites concerning steroid nuclear receptors is very useful.

\section{Worst feature}

Some links go to pages that are empty, with no logo or other content.

\section{Wish list}

A search engine could help users locate information, and spell checking would make it more useful.

\section{Related websites}

Endocrinology databases is a collection of databases on hormones and their functions in humans and animals.

\section{Table of links}

The nuclear receptor resource

Endocrinology databases

References

1. The nuclear receptor resource. 